\title{
A series of patients with minimal change nephropathy treated with rituximab during adolescence and adulthood
}

\author{
Marinus J Dekkers ${ }^{1 *}$, Jaap W Groothoff ${ }^{2}$, Robert Zietse ${ }^{3}$ and Michiel G H Betjes ${ }^{3}$
}

\begin{abstract}
Background: The treatment of immune suppression dependent minimal change nephropathy (MCN) can be challenging and frequently leads to serious complications. In paediatric patients, successful treatment with rituximab is described in steroid-dependent MCN. There is limited information about the potential efficacy of rituximab for the treatment of MCN in adults and adolescence. We describe our experience with rituximab in adolescent and adult patients with immune suppression dependent MCN.
\end{abstract}

Results: Ten adolescents and adults with immune suppression dependent $\mathrm{MCN}$ and therapy related complications were treated with rituximab. At a mean age of 26 years, about 10.5 years after first presentation, they received two doses of rituximab $\left(375 \mathrm{mg} / \mathrm{m}^{2}\right.$ ). Maintenance immunosuppressive medication was stopped. After a mean follow-up of 43 months, three patients had four relapses. Three relapses were successfully retreated with rituximab again, after induction therapy with $60 \mathrm{mg}$ prednisone per day. Rituximab was well tolerated and no infectious complications were recorded.

Conclusion: Treatment with rituximab induces a long-term remission of immune suppression dependent MCN in adolescents and adults. A timely treatment with rituximab could be considered to limit side effects of immunosuppressive medication.

Keywords: Minimal change nephropathy, Immune suppression dependent, Rituximab

\section{Background}

Minimal change nephropathy (MCN) is the most common cause of childhood onset nephrotic syndrome [1]. MCN usually responds well to prednisone, but up to $70 \%$ of the patients have one or more relapses of the nephrotic syndrome [2,3]. A considerable part may become steroid-dependent and over half of the patients with MCN require additional immunosuppressive therapy [3]. Generally the nephrotic syndrome will go into definite remission after puberty, but up to $25 \%$ of the children with MCN will continue to suffer from relapses in adulthood [4]. Patients with frequent relapses of the nephrotic syndrome are exposed to long periods of prednisone and have a high risk of therapy-related complications

\footnotetext{
*Correspondence: riendekkers@solcon.nl

1 Department of Nephrology, Erasmus MC, Room H 438, P.O. Box 2040,

3000 CA Rotterdam, The Netherlands

Full list of author information is available at the end of the article
}

[4]. Other immunosuppressive medication such as calcineurin inhibitors and cyclophosphamide can reduce the cumulative dose of steroids. However, these secondline medications may have serious side effects or limited effectiveness. In recent years, successful treatment with rituximab was described for $\mathrm{MCN}$ in children. After treatment with rituximab there are less relapses of the nephrotic syndrome and other immunosuppressive therapy could be substantially reduced [5-8]. There is limited information about the potential efficacy of rituximab for the treatment of MCN in adults and adolescence [9-16]. We describe a series of patients with immune suppression dependent $\mathrm{MCN}$, treated with rituximab in adolescence and adulthood.

\section{Results and discussion}

The patients (Additional file 1: Table S1) with a mean age of 26 (14-56) years had the first presentation of the 
nephrotic syndrome in childhood (4 cases), adolescence ( 4 cases) and adulthood ( 2 cases). The first presentation of the nephrotic syndrome was at an average age of 16 (3-52) years. The mean duration of the nephrotic syndrome was $10.5(0.5-23)$ years.

After treatment of rituximab, there was a mean followup of 43 months (16-76 months). In this period, three patients had four relapses. One patient (number 9) with a relapse after 24 months and another patients (number 5) with two relapses (21 and 36 months after initial rituximab treatment) were successfully retreated with rituximab after remission induction therapy with $60 \mathrm{mg}$ prednisone/day. Both patients still have a complete response 37 and 43 months after last retreatment with rituximab respectively.

The fourth patient (number 3) had a relapse after 21 months, but retreatment with steroids and rituximab was unsuccessful. The nephrotic syndrome came into remission with prednisone and cyclosporine maintenance therapy.

In all patients, rituximab treatment lead to a total depletion of circulating B cells for at least 1 month. After 1 month, the B cell counts were not routinely measured.

Rituximab was well tolerated, except for one patient who had an allergic reaction during the first treatment. Although the infusion of rituximab was stopped halfway the peripheral B-cells were fully depleted and the nephrotic syndrome went into complete remission without further need for maintenance immunosuppressive medication. None of the patients had infectious complications after treatment with rituximab. In contrast, all patients had experienced serious side effects of the previous (maintenance) immunosuppressive therapy (Additional file 1: Table S1).

\section{Discussion}

The treatment of immune suppression dependent MCN is challenging. Although the nephrotic syndrome usually responds well to prednisone $[17,18]$, long-term use has serious complications: obesity, cushingoid habitus, osteonecrosis and cataract. Cyclophosphamide, cyclosporine, mycophenolate mofetil or levamisole are commonly used as second-line treatment [5]. Cyclosporine maintenance therapy is usually effective, but relapses often occur after discontinuation [19]. Cyclosporine can cause renal dysfunction, hypertension and gingival hyperplasia. Mycophenolate mophetil may reduce the frequency of relapses [20], but is its use may be limited by gastrointestinal side effects. Maintenance therapy with levamisole, can reduce the number of relapses, but is not known to induce long term remission. In addition, levamisole is not available in every country and could induce agranulocytosis $[5,21]$. Only the use of cyclophosphamide may induce a long term remission of $\mathrm{MCN}$ in about half of the patients, but cytotoxicity and the risk of infertility are potential serious side effects [22].

In recent years, a number of publications in paediatric patients have reported that rituximab is an effective treatment in steroid-sensitive, but immune suppression dependent nephrotic syndrome. In these children, rituximab treatment seems to be able to reduce the relapse rate, although the immunosuppressive medication was reduced or even discontinued [5-8, 23-26]. The treatment with rituximab in steroid-resistant nephrotic syndrome is considerable less effective [24,27].

The data about the efficacy of rituximab for $\mathrm{MCN}$ in adult patients is limited, but seem to confirm the positive results in children [9-16]. Our data show that adolescents and adults with immune suppression-dependent MCN have a remarkable good long term remission in response to rituximab treatment. Even more remarkable, long term remission was achieved in patients with immune suppression dependent MCN many years after the first presentation and after different immune suppressive drugs and combinations thereof.

Although the pathophysiology of MCN is unknown, the immune system and especially the T-cells seem to play a role [28]. A circulating factor originating from patient's T-cells can induce $\mathrm{MCN}$ in animals [29]. The regulatory T-cells of patients with $\mathrm{MCN}$ are less effective compared with T-cells of healthy. When $\mathrm{MCN}$ is in remission, these regulatory $\mathrm{T}$-cells functionally improve [30]. Therefore it is interesting that administration of rituximab, a monoclonal antibody directed against CD20, expressed on B-cells, is an effective therapy. In recent years, it is reported that the B-cell has also regulatory functions. The regulatory B-cell stimulates both effector and regulatory T-cells [31]. In other auto-immune diseases the regulatory T-cell function improves after treatment with rituximab [32]. The mechanism of action is unknown, but maybe B-cell depletion results in a new balance between the various T-cell subsets. This balance may establish even after repopulation of the peripheral B-cell population. A suggested mechanism is that T-cells, that interact with B-cells, are removed simultaneous after treatment with rituximab [33]. Otherwise it is also possible that the B-cell has a direct role in the pathogenesis of $\mathrm{MCN}$, but evidence for this position is lacking.

Beside an immunological explanation, rituximab may have a direct effect in the kidney. A recent study shows that rituximab may stabilize the cytoskeleton of the podocyte [34].

We treated our patients with 2 doses of rituximab with a one- or two-week interval, when nephrotic syndrome was in complete remission. Our experience is in agreement with the notion that rituximab seems to be most 
effective as a remission maintenance drug after induction therapy to achieve complete remission of the MCN [5]. Published studies vary in their dose and number of doses rituximab to achieve long-term remission of $\mathrm{MCN}$. A single dose of rituximab achieved a good response in a series of 12 patients, described by Kamei et al., but the relapse rate was 75\% [7]. Another study observation that the time to relapse of the nephrotic syndrome was longer when initially more than three doses were given [23]. An unanswered question is whether rituximab treatment should be repeated after repopulation of the peripheral B-cell population in order to achieve protracted remission. The nephrotic syndrome relapses usually only after repopulation of the peripheral B-cell population [5, 6]. However a large part of the patients have a sustained complete remission, even after repopulation of peripheral B-cells and we therefore did not follow this strategy [6].

Rituximab was well tolerated in our patients. Only one patient had an allergic reaction and infusion was stopped. In previous studies, about $50 \%$ of the patients had some complaints when rituximab was administered, but there was no need to stop administration. These symptoms are usually mild and concerns hypotension, tachycardia, dyspnoea and cutaneous rash $[5,6]$.

Although rituximab causes an average of 6 months B-cell depletion, infectious complications are scarce $[5,6]$. A slight depression of serum immunoglobulins is described [35]. Seldom severe complications are pneumocystis jirovecii pneumonia, severe colitis and pulmonary fibrosis [5, 36, 37]. Progressive multifocal leucoencephalopathy is associated with the use of rituximab, but this complication is never described in children treated with rituximab [35]. Adverse events following treatment of rituximab may be dependent of concomitant use of immunesuppressive agents and underlying conditions [35]. After treatment with rituximab we recorded no infectious complications. These limited side-effects of the rituximab treatment are in contrast to complications the other immunosuppressive medications.

\section{Conclusion}

In conclusion, our series of patients shows a remarkable efficacy of rituximab for the induction of long-term remission of immune suppression dependent MCN in adolescents and adults. In the group of patients with immune suppression dependent MCN, with frequent relapses and therapy related complications, a timely treatment with rituximab could be considered to limit side effects.

\section{Methods}

We describe retrospective our experience with the treatment of rituximab in adolescent and adult patients with biopsy proven $\mathrm{MCN}$, who need maintenance immunosuppressive therapy for sustained remission. All patients had normal renal function. They were treated with rituximab because of serious complications due to immunosuppressive medication, frequent relapses or at patients request to stop maintenance immunosuppressive medication. When the nephrotic syndrome was in remission with immunosuppressive therapy, they were treated with 2 doses of $375 \mathrm{mg} / \mathrm{m}^{2}$ rituximab with a 1 (patients 8-10) or 2 (patients 1-7) week interval.

Following treatment with rituximab, the dose of prednisone was tapered rapidly and other immunosuppressive medication was stopped within 1 month after the last administration of rituximab.

\section{Consent}

Written informed consent for publication of this case series was obtained from all ten patients. A copy of the written consent is available for review by the Editor-inChief of this journal.

\section{Additional file}

Additional file 1: Table S1. Patients characteristics, treatment, and complications.

\section{Abbreviation}

MCN: minimal change nephropathy.

\section{Author's contributions}

MJD and MGHB drafted the manuscript. JWG and RZ revised the article. JWG, $\mathrm{RZ}$ and $\mathrm{MGHB}$ treated the patients. All authors read and approved the final manuscript.

\section{Author details}

${ }^{1}$ Department of Nephrology, Erasmus MC, Room H 438, P.O. Box 2040, 3000 CA Rotterdam, The Netherlands. ${ }^{2}$ Emma Children's Erasmus MC, P.O. Box 2040, 3000 CA Rotterdam, The Netherlands. ${ }^{3}$ Department of Nephrology, Erasmus MC, P.O. Box 2040, 3000 CA Rotterdam, The Netherlands.

\section{Compliance with ethical guidelines}

Competing interests

The authors declare that they have no competing interests.

Received: 13 December 2013 Accepted: 19 June 2015

Published online: 26 June 2015

\section{References}

1. Barnett HL, Edelman CM, Greifer I, Spitzer A, Freeman K, Arneil GC et al (1978) Nephrotic syndrome in children: prediction of histopathology from clinical and laboratory characteristics at time of diagnosis. A report of the International Study of Kidney Disease in Children. Kidney Int 13:159-165

2. Hodson EM, Knight JF, Willis NS, Craig JC (2003) Corticosteroid therapy for nephrotic syndrome in children. Cochrane Database Syst Rev CD001533

3. Esfahani ST, Madani A, Asgharian F, Ataei N, Roohi A, Moghtaderi A et al (2011) Clinical course and outcome of children with steroid-sensitive nephrotic syndrome. Pediatr Nephrol 26:1089-1093 
4. Kyrieleis HAC, Löwik MM, Pronk I, Cruysberg HR, Kremer JA, Oven WJ et al (2009) Long-term outcome of biopsy-proven, frequently relapsing minimal-change nephrotic syndrome in children. Clin J Am Soc Nephrol 4:1593-1600

5. Guigonis V, Dallocchio A, Baudouin V, Dehennault M, Hachon-Le Camus C, Afenetti M et al (2009) Rituximab treatment for severe steroid- or cyclosporine-dependent nephrotic syndrome: a multicentric series of 22 cases. Pediatr Nephrol 23:1269-1279

6. Sellier-Leclerc AL, Baudouin V, Kwon T, Macher MA, Guérin V, Lapillonne $\mathrm{H}$ et al (2012) Rituximab in steroid-dependent idiopathic nephrotic syndrome in childhood-follow-up after CD19 recovery. Nephrol Dial Transplant 27:1083-1089

7. Kamei K, Ito S, Nozu K, Fujinaga S, Nakayama M, Sako M et al (2009) Single dose of rituximab for refractory steroid-dependent nephrotic syndrome in children. Pediatr Nephrol 24:1321-1328

8. Ravani P, Ponticelli A, Siciliano C, Fornoni A, Magnasco A, Sica F (2013) Rituximab is a safe and effective long-term treatment for children with steroid and calcineurin inhibitor-dependent idiopathic nephrotic syndrome. Kidney Int 84:1025-1033

9. François H, Daugas E, Bensman A, Ronco P (2007) Unexpected efficacy of rituximab in multirelapsing minimal change nephrotic syndrome in the adult: first case report and pathophysiological considerations. Am J Kidney Dis 49:158-161

10. Hofstra JM, Deegens JKJ, Wetzels JFM (2007) Rituximab: effective for severe steroid-dependent minimal change nephrotic syndrome? Nephrol Dial Transplant 22:2100-2101

11. Sawara Y, Itabashi M, Kojima C, Tabata H, Kamei D, Kawanishi Ket al (2009) Succesful therapeutic use of a single-dose of rituximab on relapse in adults with minimal change nephrotic syndrome. Clin Nephrol 72:69-72

12. Beco A, Castro-Ferreira I, Coentrao L, Neto R, Sampaio S, Pestana M (2010) Rituximab for steroid-dependent nephrotic syndrome. Clin Nephrol 74:308-310

13. Hoxha E, Stahl RA, Harendza S (2011) Rituximab in adult patients with immunosuppressive-dependent minimal change disease. Clin Nephrol 76:151-158

14. Munyentwali $H$, Bouachi $K$, Audard V, Rwemy P, Lang P, Mojaat R et al (2013) Rituximab is an efficient and safe treatment in adults with steroiddependent minimal change disease. Kidney Int 83:511-516

15. Takei T, Itabsahi M, Moriyama T, Jojima C, Shiohira S, Shimizu A et al (2013) Effect of single-dose rituximab on steroid-dependent minimal change nephrotic syndrome in adults. Nephrol Dial Transplant 28:1225-1232

16. ADD 3, Ruggenenti $P$, Ruggiero B, Cravedi $P$, Vivarelli M, Massella L, Marasà M (2014) Rituximab in steroid-dependent or frequently relasping idiopathic nephrotic syndrome. J Am Soc Nephrol 25:850-863

17. Saha TC, Singh H (2006) Minimal change disease: a review. South Med J 99:1264-1270

18. Koskimies O, Vilska J, Rapola J, Hallman N (1982) Long-term outcome of primary nephrotic syndrome. Arch Dis Child 57:544-548

19. Waldman M, Crew RJ, Valeri A, Busch J, Stokes B, Markowitz G et al (2007) Adult minimal-change disease: clinical characteristics, treatment, and outcomes. Clin J Am Soc Nephrol 2:445-453

20. Dorresteijn EM, Kist-van Holthe JE, Levtchenko EN, Nauta J, Hop WC, van der Heijden AJ (2008) Mycophenolate mofetil versus cyclosporine for remission maintenance in nephrotic syndrome. Pediatr Nephrol 23:2013-2020
21. Durkan AM, Hodson EM, Willis NS, Craig JC (2001) Immunosuppressive agents in childhood nephrotic syndrome: a meta-analysis of randomized controlled trials. Kidney Int 59:1919-1927

22. Mak SK, Short CD, Mallcik NP (1996) Long-term outcome of adult-onset minimal-change nephropathy. Nephrol Dial Transplant 11:2192-2201

23. Kemper MJ, Gellerman J, Habbig S, Krmar RT, Dittrich K, Jungraithmayr T et al (2012) Long-term follow-up after rituximab for steroid-dependent idiopathic nephrotic syndrome. Nephrol Dial Transplant 27:1910-1915

24. Gulati A, Sinha A, Jordan SC, Hari P, Dinda AK, Sharma S et al (2010) Efficacy and safety of treatment with rituximab for difficult steroid-resistant and -dependent nephrotic syndrome: multicentric report. Clin J Am Soc Nephrol 5:2207-2212

25. Sinha A, Bagga A, Gulati A, Hari P (2012) Short-term efficacy of rituximab versus tacrolimus in steroid-dependent nephrotic syndrome. Pediatr Nephrol 27:235-241

26. Ravani P, Magnasco A, Edefonti A, Murer L, Rossi R, Ghio L et al (2011) Short-term effects of rituximab in children with steroid- and calcineurindependent nephrotic syndrome: a randomized controlled trial. Clin J Am Soc Nephrol 6:1308-1315

27. Magnasco A, Ravani P, Edefonti A, Murer L, Ghio L, Belingheri M et al (2012) Rituximab in children with reistant idiopathic nephrotic syndrome. J Am Soc Nephrol 23:1117-1124

28. Shalhoub RJ (1974) Pathogenesis of lipoid nephrosis: a disorder of T-cell function. Lancet 7:556-560

29. Grimbert P, Audard V, Remy P, Lang P, Sahali D (2003) Recent approaches to the pathogenesis of minimal-change nephrotic syndrome. Nephrol Dial Transplant 18:245-248

30. Araya C, Diaz L, Wasserfall C, Atkinson M, Mu W, Johnson R et al (2009) T regulatory cell function in idiopathic minimal lesion nephrotic syndrome. Pediatr Nephrol 24:1691-1698

31. Thaunat O, Morelon E, Defrance T (2010) Am "B" valent: anti-CD20 antibodies unravel the dual role of B cells in immunopathogenesis. Blood 116:515-521

32. Stasi R, Del Poeta G, Stipa E, Evangelista ML, Abruzzese E, Amadori S (2007) Response to B-cell-depleting therapy with rituximab reverts the adnormalities of T-cell subsets in patients with idiopathic thrombocytopenic purpura. Blood 110:2924-2930

33. Datta SK (2009) Anti-CD20 antibody is an efficient therapeutic tool for the selective removal of autoreactive T-cells. Nat Clin Pract Rheumatol 5:80-82

34. Fornoni A, Sageshima J, Wei C, Merscher-Gomez S, Robier A-P, Jauregui AN (2011) Rituximab targets podocytes in recurrent focal segmental glomerulosclerosis. Sci Transl Med. doi:10.1126/scitranslmed.3002231

35. Cooper N, Arnold DM (2010) The effect of rituximab on humoral and cell mediated immunity and infection in the treatment of autoimmune diseases. Br J Haematol 149:3-13

36. Ardelean DS, Gonska T, Wires S, Cutz E, Griffiths A, Harvey E et al (2010) Severe ulcerative colitis after rituximab therapy. Pediatrics 126:e243-e246

37. Chaumais MC, Garnier A, Chalard F, Peuchmaur M, Dauger S, Jacqz-Agrain E et al (2009) Fatal pulmonary fibrosis after rituximab administration. Pediatr Nephrol 24:1753-1755

\section{Submit your next manuscript to BioMed Central and take full advantage of:}

- Convenient online submission

- Thorough peer review

- No space constraints or color figure charges

- Immediate publication on acceptance

- Inclusion in PubMed, CAS, Scopus and Google Scholar

- Research which is freely available for redistribution

Submit your manuscript at

www.biomedcentral.com/submit
C Biomed Central 